logos_i_ethos_2020_special issue, pp. 133-157

DOI: http://dx.doi.org/10.15633/lie.3771

Rafał S. Niziński

https://orcid.org/0000-0003-3566-0861

\title{
Rationality or reasonableness: an attempt at changing the paradigm of philosophical cognition of God - thought of Xavier Zubiri
}

One of the commonly encountered objections to the classical proofs of the existence of God and I have in mind, for instance, the proofs put forward by Thomas Aquinas - is that the "proven" God is not a God of religion, but a God of philosophy. This gives rise to the situation whereby the obtained image of God does not encourage man to enter into a relationship with Him, and so it does not encourage religious faith. The task Rafał S. Niziński - Ph. D., an Assistant Professor at the Unit of Christian Philosophy at AMU. He specialises in the philosophy of religion, and so by extension also in metaphysics and epistemology. His studies have so far encompassed: Martin Heidegger's metaphysics, Charles Hartshorne's philosophy of God, Karl Barth's theology - the problem of rationality of faith, Xavier Zubiri's philosophy of God (the present field of study), Carmelite mysticism as represented by Saint John of the Cross and Saint Teresa of Avila, as well as philosophy of mysticism. He has published several books, papers and studies under his own editorship. of finding such a path leading to God that would afford us His image which would perform the role of both a religious and a philosophical image has been undertaken by a number of thinkers. ${ }^{1}$ Xavier Zubiri espouses this current. ${ }^{2}$ In order to achieve this, Zubiri propounds his own paradigm of cognition of God. He considers that it is not rationality but reasonableness that leads to the

1 Cf. Ch. Hartshorne, Man's Vision of God and the Logic of Theism, Connecticut 1964, p. IX; M. Jędraszewski, Bóg filozofów i Bóg Jezusa Chrystusa, Poznań 2011, pp. 65-70.

2 X. Zubiri, El problema filosófico de la historia de las religiones, Madrid 2006, pp. 40, 55; see F. Llenín Iglesias, La realidad divina. El problema de Dios en Xavier Zubiri, Oviedo 1990, p. 106. 
cognition of God. If rational cognition is limited to purely intellectual efforts, then reasonableness - according to Zubiri - is a broader concept inclusive of rational cognition. Reasonableness opens up to will and feelings, ascribing to them some cognitive role.

With regard to Zubiri's above-mentioned postulate, it is just to ask whether the concept of God presented by this philosopher allows God to be a God of both philosophy and religion. Also, whether the method of cognition of God put forth by Zubiri can function outside his philosophy as well.

Since Zubiri's manner of reaching God is supposed to fulfil two roles, the obtained concept of God should meet some standards of rational thinking, and at the same time it should encourage man to enter into a religious relationship with God thus revealed. ${ }^{3}$

\section{Inadequacy of metaphysical proofs}

Zubiri begins with enumerating reasons for which the previous metaphysical proofs have failed to fulfil their roles. The philosopher directly refers to the classical proofs developed by Saint Thomas Aquinas. ${ }^{4}$ He makes several objections to them.

The first objection states that the starting point for these ways is preceded by a certain theory. However, the God whom we are to become cognizant of cannot be a God of some theory, but a God of reality. ${ }^{5}$ This objection is in keeping with the phenomenological paradigm of cognition that Zubiri ${ }^{6}$ refers to. In his opinion, Thomas' prima via is not about motion, but about moving from potency to act, which is not a fact, but already some kind of interpretation of movement. Secunda via seems dubious, because only man can be an efficient cause. Any other cases are only regular consequences of events. To say that under

\footnotetext{
See X. Zubiri, El hombre y Dios, Nueva edición, Madrid 2012, pp. 246-247.

4 Thomae Aquinatis, Summa theologiae, Matritii 1978, I, q. 2, a. 3.

5 See X. Zubiri, Inteligencia y razón, Madrid 2008, pp. 15, 32, 82.

6 See X. Zubiri, El problema filosófico de la historia..., op. cit., pp. 288-289, 294.
} 
certain circumstances an efficient cause is in operation is already an interpretation of experience. In tertia via Thomas finds it to be a fact that things come into and go out of existence at the same time, i.e. the contingency of their existence is understood to be a fact. Zubiri rejects such a view, because that which is possible and necessary is not given in experience. By the same token, the contingency of all beings is not given in experience. Likewise, Zubiri critiques Thomas' other ways. ${ }^{7}$ The Spanish philosopher does not enter into a polemic with Thomas over the soundness of his conclusions - the existence of pure actuality being a fitting example here - but over the fact that Thomas fails to abide by his own claim to begin with facts.

The second objection with regard to the above ways is concerned with the conclusion that Thomas draws. Five different conclusions do not necessarily have to point to one and the same being, i.e. God. For that to be the case, one first needs to demonstrate it. ${ }^{8}$

The third objection too remains an open question: whether the supreme being (ente supremo) is God? Zubiri mentions the deliberations on this issue engaged in by Duns Scotus. ${ }^{9}$ In the second part of his proof, Duns Scotus aims to demonstrate that the prime mover, whose existence he has proved, is infinite, which means that he is God, for Scotus finds infinity to be the attribute of God. Therefore, Zubiri asks whether that which is infinite must be God. He himself rejects such a concept. In his opinion, Scotus is just looking for a metaphysical being - to use scholastic terminology - and not God. ${ }^{10}$ That is why Thomas Aquinas' supreme being as pure actuality, or a necessary being, are just notions of the most perfect beings, which do not necessarily mean God.

7 See X. Zubiri, El hombre y Dios, op. cit., pp. 136-138.

8 See X. Zubiri, El hombre y Dios, op. cit., p. 139.

9 Cf. F. T. Janka, Jana Dunsa Szkota dowód na istnienie Boga, in: Primum philosophari. Opuscula Antonio Siemianowski dedicata, Poznań 2016, pp. 123-132.

10 See X. Zubiri, El hombre y Dios, op. cit., p. 139-140. 


\section{The rational stage on the way to God}

\section{A wrong starting point?}

As Zubiri is looking for the right starting point for attaining knowledge of God, he notes that it must be man, and more specifically - the human person. As he makes man the starting point, he notes that man cannot approached in a random manner. By way of illustration, he briefly mentions anthropological ways of discovering God that have been pursued by other philosophers. And so he analyses the proof provided by Saint Augustine, who - in Zubiri's opinion - starts out with the finite truth which man gets to know, and which is supposed to lead to the complete truth. ${ }^{11}$ Then he goes on to present Immanuel Kant's proof, whereby the will is categorically expected to will from duty, which requires the existence of good in itself. ${ }^{12}$ Last but not least, he mentions Friedrich Schleiermacher's proof based on the feeling of absolute dependence upon the infinite. The feeling is concerned with irrational and infinite reality. ${ }^{13}$ In consequence, these three proofs based on the analysis of human intelligence, will and feeling would lead - as was intended by their authors - to independent truth, perfect good and infinite reality, i.e. God. ${ }^{14}$ Zubiri is doubtful whether the three mentioned aspects of man, with which the proofs begin, are really facts. Besides, they approach man only partially. But man must be approached comprehensively. Third objection: all these thinkers espouse a dualist vision of man. ${ }^{15}$ Therefore, the starting point on the way to God is already determined by a certain vision of man, whereby he is in opposition to reality. The consequence

11 In his proof, Augustine moved from the cognition of immutable and necessary truths to God, who is the highest truth. See Augustyn z Hippony, O wolnej woli, trans. A. Trombala, in: Augustyn z Hippony, Dialogi filozoficzne, Kraków 1999, Rev. II, VIIInn.

12 I. Kant, Krytyka praktycznego rozumu, trans. J. Gałecki Warszawa 1972, pp. 201-202, 256-257.

13 Cf. M. Potępa, Obraz człowieka w hermeneutyce Schleiermachera, "Analiza i Egzystencja" 19 (2012), p. 126.

14 See X. Zubiri, El hombre y Dios, op. cit., p. 141.

15 See X. Zubiri, El hombre y Dios, op. cit., pp. 142-143. 
is the image of God separated from the world. Even though these three authors want God to be integrated with the world, and in fact they do integrate Him with the world, the necessity for this integration is the most nagging drawback to their proofs. God thus construed is separated from the world, and connected only with man. The partial character of these three aspects of man, their intrinsic dualism, the opposition of God and the cosmos are all, according to Zubiri, shortcomings of the proofs in question. ${ }^{16}$

\section{What should the right starting point be?}

Zubiri says that the right path to God should begin the moment when we deal with reality operating in a manner showing that it is something ultimate. ${ }^{17}$ This happens in the case of creating (moulding) the human Self. And so the first step will be about delving into how Zubiri understands man and the person. The thinker rejects the concepts of being and substance. For him every thing (person) is a reality with certain characteristics. The very concept of reality has several meanings: a reality of a specific thing, a reality as a set of all things, and a reality as a foundation of things. Reality in the latter sense denotes God, who is essentially present in every thing (demonstrating His existence and cognition of His nature is the goal that can be attained by the manner of cognition of God that we are analysing now).

Zubiri calls man a personal substantive reality (realidad sustantiva). As a person he possesses himself. Through his acts, a person accomplishes self-affirmation, thereby creating his personality, i.e. the Self. Zubiri stresses that the Self (a personality) is not a person, but being ( $\mathrm{el} \mathrm{ser}$ ) of the person, and the person's being is a certain manner of his finding himself in the world, i.e. relating to the reality external to the person

16 See X. Zubiri, El hombre y Dios, op. cit., pp. 142-143.

17 "Si en la realidad descubrimos alguna dimensión que de hecho envuelva constitutiva y formalmente un enfrentamiento inexorable con la ultimidad de lo real, esto es, con lo que de una manera meramente nominal y provisional podemos llamar Dios" (X. Zubiri, El hombre y Dios, op. cit., pp. 5-6); cf. A. Ferraz Fayos, Zubiri: el realismo radical, Madrid 1988, p. 200. 
(a reality of things and other persons). By configuring his being, that is relating to the reality external to himself, a person changes this being, which enables his personal life. ${ }^{18}$ A personality is "a certain mode of being, a form of that which the human reality makes itself into during its lifetime." ${ }^{19}$ It is important to capture the dependence of a personal life on the reality external to the person. Without this reality there would be no personal life.

The above can be expressed differently. Zubiri acknowledges that man is not a reality (realidad) made once and for all, but he creates himself in a precise manner. On the one hand, man is his own reality (realidad „suya”). Being one's own reality is about possessing oneself, and that is what makes a human being a person (persona). On the other hand, man stands face to face with all reality, which is not his own reality, but is external to him. In this sense, one might say that a person is free/separate (está "suelta" de toda otra realidad) from all other reality: he is absolute ("ab-soluta"). However, a person's absoluteness is relative, because it has been received/obtained (cobrada). What does Zubiri have in mind when he says that a person is a relative absolute (relativamente absoluto)? In respect of his personality, he creates himself, moulding his own reality. This is accomplished by man's ever new reference to something that is external to him. ${ }^{20}$

The effect that the external reality has on a person consists in enabling the person to change his own reality, that is to configure his Self. That is the point at which manifest becomes the ultimate character of the operation of the external reality with reference to the person. Zubiri notes that the configuration of the human Self is effected thanks to things. He writes that thanks to things ${ }^{21}$ man configures the being of his own substantive reality, that is he creates his own Self, because he always finds himself in some relation to them. Man lives and creates his being thanks to reality

21 "desde las cosas va a configurar el ser de su propia realidad sustantiva." 
(desde la realidad). It is reality that makes man continually configure his Self. Also, reality is man's ultimate (último) support in his configuration of his Self. Reality plays this role with regard to Self on account of its own realness, and not because of the characteristics of particular things that make up reality. ${ }^{22}$

As regards the issues concerned with the person, Zubiri's terminology is complicated. It is important to realise that the terms "personality" and "Self" are close in meaning, and that the life of a person as a person consisting in personality change is about configuring a person's being thanks to the reality external to the person. ${ }^{23}$ A personal life is about "obtaining a personality [the Self]. This is done in every act performed by a person. It consists in a person obtaining some form of reality."24

Zubiri points out that reality has some power over a person by changing his Self. He calls this power the power of reality. Religation is about the dependence of a person in his personal life on the reality external to him. ${ }^{25}$ The power of reality to which a person is religated forms a foundation, i.e. the underpinning of a personal life. In other words, thanks to reality a person can fulfil himself as a person, because it is only the reality external to the person that enables him to take on a new form of being, which in turn constitutes a personal life. ${ }^{26}$ One of the commentators presents it thus: self-possession, which makes a human being a person, is a peculiarly human characteristic. A person affirms himself thanks to his reference to other things and to himself. A human being is not outside reality, nor does he make himself by referring to himself only, but he must make himself inside reality along with other real things. ${ }^{27}$

22 See X. Zubiri, El problema filosófico de la historia..., op. cit., pp. 38-40.

23 See X. Zubiri, El hombre y Dios, op. cit., pp. 145-147.

24 M. Jagłowski, Realizm transcendentalny..., op. cit., p. 186.

25 See X. Zubiri, El hombre y Dios, op. cit., p. 8.

26 See X. Zubiri, El hombre y Dios, op. cit., pp. 89-91, 155; D. Gracia, El tema de Dios en la filosofía de Zubiri, "Estudios Eclesiásticos" 56 (1981) no. 216-217, p. 74.

27 Cf. A. Pintor-Ramos, Religación y “prueba” de Dios en Zubiri, „Razón y Fe” 218 (nov. 1988) no. 1081 , pp. $324-325$. 
Zubiri does not share the opinion that referring to the reality external to the person is only a mental act. ${ }^{28}$ It is something much more significant - it has metaphysical consequences, enabling creation of Self. ${ }^{29}$ The Self, i.e. a person's being, is metaphysical in character. ${ }^{30}$ It is precisely under such circumstances that we come to deal with the ultimate character of the operation of reality with regard to man. The fact that reality becomes something ultimate for man implies that in this respect of its operation we might be dealing with God.

The important point here is that according to Zubiri religation is a fact. ${ }^{31}$ Its factual status means that religation is no mere theory, because the dependence of a person's being on reality is obvious, as we all experience it. The whole of my personal reality, in all its dimensions, is religated to the power of reality. ${ }^{32}$ Of course, I create the new form of my personal self through my reference to reality, but without the reality external to me I would not be able to accomplish that. The dependence on reality and its inherent power is to be found in all things. It is only in the case of man, on account of dominance over the human person, that this operation affects the human intelligence, and it is only man that has access to this operation as if from within, as he experiences it inside of himself. ${ }^{33}$ This is because on account of the acts of intelligence a person configures his being. ${ }^{34}$ It is exactly this that enables access, which is unmediated by any previous theory (accesible a un análisis inmediato), to the relation between the person and reality (and by extension to the dependence on God). According to Zubiri, in Thomas Aquinas' philosophy creating and moving beings is already some kind of interpretation of reality, and not a fact. This is because we do not

\footnotetext{
28 See X. Zubiri, El hombre y Dios, op. cit., pp. 59-60.

29 See X. Zubiri, El hombre y Dios, op. cit., p. 83.

30 See X. Zubiri, El problema filosófico de la historia..., op. cit., p. 35.

31 See X. Zubiri, El hombre y Dios, op. cit., p. 272.

32 See X. Zubiri, El hombre y Dios, op. cit., pp. 145-147.

33 See X. Zubiri, El hombre y Dios, op. cit., pp. 22-23. See X. Zubiri, El hombre y Dios, op. cit.,

34 See X. Zubiri, El hombre y Dios, op. cit., pp. 6, 151; F. Llenín Iglesias, La realidad divina..., op. cit., p. 100.
} p. 30. 
experience the efficient cause or the cause of motion, but we can only observe the consequences of events. Hence, Thomas Aquinas is wrong when he embarks on his way to God by beginning with some reality aspects unconnected with man - writes Zubiri. Likewise wrong is the way followed by Saint Augustine and the like, because they did not include man in that which makes him ultimately (entirely) dependent on reality, because it is only for a person that reality is something ultimate. Zubiri summarises this argumentation, concluding that the ultimate (la ulterioridad) operation of reality manifests itself in the moulding of a person's being. ${ }^{35}$ On the other hand, if we begin discussion with the concept of religation we will be dealing not with God who only serves as an explanation of some process in the world of beings, but with God who enables establishment of a religious relationship with Him, because He is responsible for man's personal life in its entirety. ${ }^{36}$

On what grounds can be surmise that the power of reality with regard to the Self provides a possibility of attaining God? This results from the above-performed analysis of the character of reality operation. The power of reality has a unique and special character (supremo) in relation to the human person, because it is a constitutive foundation of my Self. ${ }^{37}$ Besides, reality is something that affords the person possibilities concerned with the choice of one or another form of being. Reality also precludes passivity, as it forces a person to take some stand on reality. ${ }^{38}$ It is these three characteristics of reality's dominance over the person that form the foundations for the surmise that at the present moment we are dealing with a manifestation (at least nominal one) of God's action. What is more, in these three characteristics religation implies an outline of the idea of God. ${ }^{39}$

35 See X. Zubiri, El hombre y Dios, op. cit., pp. 148-149.

36 See X. Zubiri, El hombre y Dios, op. cit., p. 205.

37 See X. Zubiri, El hombre y Dios, op. cit., p. 149.

38 See X. Zubiri, El hombre y Dios, op. cit., pp. 89-91.

39 See X. Zubiri, El hombre y Dios, op. cit., pp. 147-148; G. Díaz Muńoz, Búsqueda de Dios en el misterio según X. Zubiri, “Estudios Eclesiásticos” 84 (2009) no. 328, p. 148. 
As we summarise this stage of argumentation related to the cognition of God, we have grounds to surmise that God is the reality that underpins the three characteristics of the operation of reality with regard to the person. Why does this role of reality with regard to the Self require the existence of God? Because such an operation of reality with regard to the Self is problematic (enigmatico), i.e. it is not explicable in terms of what things (as reality not mine) are. For this reason, Zubiri says that every thing is its own reality (su realidad) and a presence of another reality ("la" realidad). Things have some power over the person, and this power cannot be explained in terms of their own reality (su realidad). They need something that endows them with this power, and that something must be their foundation that lies in themselves. ${ }^{40}$ If we do not know what this foundation is, creating the human Self is problematic. Therefore, God must be the foundation of the power of reality, that is He must enable (elucidate) religation. ${ }^{41}$ Hence, He should be the ultimate foundation that creates possibilities and stimulates the Self in the making. The image of God thus outlined is for the time being only a certain idea of God as God. ${ }^{42}$ If, therefore, there is God, then He is a reality that acts as the foundation for the person and things, because the creation of the Self is only possible through contact with things. ${ }^{43}$

The above statements raise doubts as to whether religation is in fact that profoundly metaphysical in character, or perhaps what we are dealing with at the present moment is but a superficial change? The creation of the Self that Zubiri mentions is not about creating "from scratch," but about changing something previously real. Mieczysław Jagłowski makes it even more specific: "Since a person is something actual (real), personalisation as a new, secondary act, or as reactualisation is an act of

40 See X. Zubiri, El hombre y Dios, op. cit., pp. 162-164; X. Zubiri, Inteligencia y razón, op. cit., pp. 63-64; J. Sáez Cruz, La accesibilidad de Dios: su mundanidad y transcendencia en X. Zubiri, Salamanca 1995, p. 215; F. Llenín Iglesias, La realidad divina..., op. cit., pp. 107-108; A. PintorRamos, Dios y el problema de la realidad en Zubiri, "Cuadernos de Pensamiento" 1987 no. 1, p. 113.

41 See X. Zubiri, El hombre y Dios, op. cit., p. 165.

42 See X. Zubiri, El hombre y Dios, op. cit., p. 148.

43 See X. Zubiri, El hombre y Dios, op. cit., p. 149. 
person's self-affirmation as identical with himself." ${ }^{\prime 4}$ The response that Zubiri might offer to the posed question is that without the dominance of the reality over the Self there would be no personal life, which is intrinsic to the essence of man. ${ }^{45}$ Since on account of its realness reality provides the foundation for my personal reality, its dominance over the Self is not something superficial, but is ultimate in character, that is without its physical dominance my Self would not be possible. ${ }^{46}$ Religation must, therefore, be metaphysical and essential for the personal life.

\section{Postulating the foundation of reality}

And thus we have defined the starting point on the way to cognition of God. It is the power of reality over the person, and this power calls for explication. Things in themselves do not reveal that which endows them with such a power. Nevertheless, importantly, they imply something on account of their manner of influencing a person. How can one move from this problem to its explanation? By drawing an analogy to Thomas Aquinas' proof from motion, one might say that we are at the moment when Thomas realises that the things we come into contact with do not explain, for instance, motion in the cosmos, and that is why he postulates the existence of pure actuality explaining the existence of motion in the world. In every case moving from the premises to the conclusion, on the ways followed by Thomas, is unambiguous in the sense that the starting point of each one of these proofs is concerned with one precise aspect of reality. As regards the way taken by Zubiri that is not the case, because we are not able to unambiguously indicate what the foundation of reality should be like. Why? In the case of motion, the matter appears to be obvious, because if we do not presuppose the existence of pure actuality, motion will be inexplicable. However, as regards the creation of the Self

44 M. Jagłowski, Realizm transcendentalny..., op. cit., p. 186. Jagłowski speaks about "quasicreation" in this case (p. 173); cf. A. Pintor-Ramos, Religación y..., op. cit., pp. 325-326.

45 See X. Zubiri, El hombre y Dios, op. cit., pp. 145-157.

46 See X. Zubiri, El hombre y Dios, op. cit., pp. 93-94. 
in Zubiri's opinion there is nothing that would clearly imply the nature of the foundation of reality. ${ }^{47}$ The foundation, though present in things and really projecting its influence, is invisible to us. ${ }^{48}$ Things are merely its resonators, adumbrating its profile. ${ }^{49}$ Reality at most implies a certain direction in the quest for the foundation. ${ }^{50}$ This direction is determined by the three above-mentioned features characterising the dominance of reality over the person, but that is quite a general suggestion. ${ }^{51}$ This is perfectly evidenced by the history of religion which is a testimony to the quest for the foundation. ${ }^{52}$

What should, then, be the next step on the way to finding God? Because there is no direct transition from the dominance of reality to its foundation, the image of the foundation must be thought up by man. An outline of the foundation is necessary, because without this outline we will not know what we are looking for. ${ }^{53}$ However, despite some suggestions as to the foundation of reality, creating an outline of its foundation is arbitrary. ${ }^{54}$

A systematic reconstruction of the description of the outlining of the image of God that Zubiri carries out is undertaken by Jesús Sáez Cruz. Zubiri proposes an outline that includes the above-mentioned characteristics of man as a relatively absolute reality that is physically dependent on the power of reality, which with regard to the Self is something ultimate, compelling and offers possibilities. According to Zubiri, the outlined image of God should explicate and enable these facts.

47 See X. Zubiri, El hombre y Dios, op. cit., p. 244; X. Zubiri, Inteligencia y razón, op. cit., p. 107.

48 See X. Zubiri, El problema filosófico de la historia..., op. cit., pp. 59-60, 293-294; M. Jagłowski, Realizm transcendentalny..., op. cit., p. 111.

49 See X. Zubiri, El problema filosófico de la historia..., op. cit., p. 304.

50 See X. Zubiri, El hombre y Dios, op. cit., p. 200, 244-244; X. Zubiri, Inteligencia y razón, op. cit., pp. 22-23.

${ }_{51}$ See X. Zubiri, El hombre y Dios, op. cit., p. 10; X. Zubiri, Inteligencia y razón, op. cit., p. 62.

52 Cf. E. Solari, La raíz de lo sagrado. Contribuciones de Zubiri a la filosofía de la religión, Santiago de Chile 2010, pp. 356-357.

53 See X. Zubiri, El problema filosófico de la historia..., op. cit., p. 296; X. Zubiri, Inteligencia y razón, op. cit., pp. 220-221.

54 See X. Zubiri, Inteligencia y razón, op. cit., pp. 109, 147-148, 211-212. 
Hence, God should be the ultimate reality, a source of the possibility of choice of forms in which man will realise his personal life, a force that compels man to choose. ${ }^{55}$ God should be personal in order to enable our personal life and entry into a personal relationship with Him in appreciation of the fact that we can live. ${ }^{56}$ Therefore, He should be an "absolutely absolute" reality, a constitutive element of reality, and of the power conveyed therein, present in every thing. ${ }^{57}$ God's real presence in things should be thus: that every thing is established "in" God, and God is present "in" it. Things should be God's life ad extra, in its finite form. In other words, things should be a God's projection ad extra. ${ }^{58}$ Another stage in outlining is deduction, which starts out with understanding God as an absolutely absolute reality. God (in Himself) should be a reality separate from existing things, being an absolute of Himself (de suyo). ${ }^{59}$ $\mathrm{He}$ is one and only reality. $\mathrm{He}$ is an absolute plenitude of "giving of Himself" (dar de si). This giving of Himself to Himself is self-possession, an absolute life. God is an actuality to Himself, i.e. He is a person. He possesses intelligence and will. ${ }^{60}$ In relation to things $\mathrm{He}$ is a founding reality. ${ }^{61}$

As the above outline proceeds, it must be borne in mind that God's characteristics contained therein are not included by necessity, because in the experience of reality we encounter an ambiguous suggestion as to the direction of quest for the foundation. In the process of creating the outline we are, therefore, free and we can accept any inspiration. In

55 See X. Zubiri, El hombre y Dios, op. cit., pp. 170-172.

56 See X. Zubiri, El hombre y Dios, op. cit., pp. 204-211; X. Zubiri, El problema filosófico de la historia..., op. cit., pp. 70-72; X. Zubiri, Naturaleza, Historia, Dios, Madrid 2007, p. 412; M. D. González, Dios, problema de todos, in: Voluntad de vida. Ensayos filosóficos, Seminario Zubiri Ellacuría, Managua 1993, p. 80.

57 Cf. J. Sáez Cruz, La accesibilidad de Dios..., op. cit., pp. 213-214.

58 Cf. J. Sáez Cruz, La accesibilidad de Dios..., op. cit., p. 217.

59 See X. Zubiri, El hombre y Dios, op. cit., p. 149.

60 See X. Zubiri, El hombre y Dios, op. cit., p. 187nn.

61 Cf. J. Sáez Cruz, La accesibilidad de Dios..., op. cit., pp. 218-219. 
the outline in question, Zubiri knowingly draws inspiration from the Christian vision of God. ${ }^{62}$

In the above statements, as we follow Zubiri, we have been trying to rationally explain what could make religation possible. ${ }^{63}$ But the reasoning done so far constitutes merely the first - intellectual (intelectivamente) - part of the way to God which on the basis of observation and then its own invention is followed by the intellect. ${ }^{64}$ The accomplished stage of reasoning is a rational element in the way to God, in the sense that involved becomes only the intellect, which - as it has a direct access, not preceded by any theory, to religation - describes it. Then, the intellect draws conclusions, trying to explain religation by creating some outline of the foundation. ${ }^{65}$ But this stage is not conclusive, because religation can be explained in many ways, which is evidenced by the history of religion.

\section{The reasonable stage of the way to God}

The second stage of the way leading to the cognition of God is concerned with checking whether the above-outlined concept of God is true. So far it meets the requirements of the intellect, because it is one of the possible rational explanations of religation. Nevertheless, we cannot be certain whether that is the true image of God, because religation may as well be explained pantheistically, panentheistically or theistically, which - according to Zubiri - is the case of the above outline. ${ }^{66}$ How can we, then, become confident about the truthfulness of this outline of God?

If such an image of God as the foundation of reality is the one that endows man with a capacity for personal life, then with a view to verifying

62 Cf. E. Solari, La raíz de lo sagrado..., op. cit., p. 349.

${ }^{63}$ See X. Zubiri, El hombre y Dios, op. cit., p. 195.

64 See X. Zubiri, El hombre y Dios, op. cit., pp. 152, 195.

65 See X. Zubiri, El hombre y Dios, op. cit., p. 6.

66 This issue certainly needs discussing. Cf. R. S. Niziński, Panenteísmo en la filosofía de Xavier Zubiri, “The Xavier Zubiri Review” 14 (2016-2108), pp. 5-15. 
its truthfulness, ${ }^{67}$ the image should be "placed" in one's own personal life. Thus we can verify its truthfulness. Here, Zubiri uses the term "experience" (experiencia) and "trying" (probación). ${ }^{68}$ Verification of the outline consists in entrusting/surrendering oneself (entrega) to God, who offers Himself (is outlined) in the power of reality. Only in this way can we have full access to Him. While religation is about undeveloped access to God, entrustment is about full access. ${ }^{69}$ Entrustment is an active attitude in which man accepts being led by the power of reality and (still putative) God, who underpins its foundation, and whose image he has outlined. Entrustment to God is an interpersonal action in which man offers himself to God, who offers Himself in things. This giving oneself to God manifests itself in various forms. On account of the fact that in religation things are man's ultimate support in his personal life, God, who acts in them, is the one who is entitled to reverence, obedience, adoration and moral adjustment. Because reality provides a person with possibilities of choice, God is the one we can turn to, asking for help in prayer. The outline contains an image of God that is attractive to us and as it were makes us continually take a stand on reality. Hence, God is a shelter and support for man. Such attitudes are not characteristic of a specific religion, but they are a justified response to that which is experienced in religation. ${ }^{70}$

Until the moment the outline of the foundation of reality is created it is only the human intellect that has been involved. For entrustment to be possible the entire human person should become committed. There is a need for will to accept that God offers Himself to me in things, and so I entrust myself to Him. Here, Zubiri speaks about a peculiar conception

67 At this point one should perhaps refer to the particulars of Zubiri's method, and introduce the reader to such terms as: logos, a referential system, reason, the world, experience (experiencia), verification of the outline. Given the character of the present paper that is not possible. A detailed explanation of these terms can be found in Jagłowski's book.

68 See X. Zubiri, Inteligencia y razón, op. cit., pp. 225-242.

69 See X. Zubiri, El hombre y Dios, op. cit., p. 214.

70 See X. Zubiri, El hombre y Dios, op. cit., pp. 216-218; D. Gracia, El tema de Dios..., op. cit., p. 76 . 
of faith $(f e)$ in the sense of entrustment to God as the true One, i.e. the One who offers being. ${ }^{71}$ When man stops short at the level where he becomes cognizant of God acting in things, but does not surrender himself to Him, then God is treated as an object. This happens in classical theology and philosophy, e.g. in Thomas' proofs. ${ }^{72}$ However, for Zubiri access to the reality-foundation can never be only purely intellectual, because the foundation is a person. ${ }^{73}$

Zubiri speaks about the will to be (voluntad de ser) in the event of the unity of cognition of God present in religation and the will to entrust oneself to God. The will to be is not a mere tendency to be. It is about assimilating specific forms of reality in order to be, because man lives by configuring his being. The will to be is associated with the will to truth (voluntad de verdad), which - as it comes down to the presence of reality in intelligence - offers a whole wealth of reality, that is its constancy and effectiveness of realness (patencia, firmeza, efectividad), thereby consolidating a person's being. ${ }^{74}$ The will to be can be opposed to the will to create ideas (voluntad de verdad de ideas). A man who adopts the latter attitude does not enter into a personal relationship with the foundation of reality, but he treats it as an object, without verifying/testing the outlined images of God in his own life. ${ }^{75}$ Zubiri finds the conformity of the postulated image of God with my personal self to be a crucial criterion for verifying the outline of God. I must test the outlined image of God within myself, because only when I religate my Self to the power of reality do I have a capacity for insight into the nature of religation from within, and for finding a real conformity between the outlined image of God and His effective action in my personal life. ${ }^{76}$

71 See X. Zubiri, El hombre y Dios, op. cit., p. 246.

72 See X. Zubiri, El hombre y Dios, op. cit., pp. 247-248.

73 Cf. A. Pintor-Ramos, Dios y..., op. cit., p. 117.

74 See X. Zubiri, El hombre y Dios, op. cit., pp. 258-262; M. D. González, Dios, problema de todos, op. cit., p. 80.

75 See X. Zubiri, El hombre y Dios, op. cit., pp. 262-269.

76 See X. Zubiri, El hombre y Dios, op. cit., pp. 232-233; see X. Zubiri, Inteligencia y razón, op. cit., p. 215. 
When a man accepts the reality-foundation (God) as his, then he allows it to happen in himself, making it (this foundation) his own. What is more, in a sense he becomes similar to the foundation (vive en la figura de su fundamento). ${ }^{77}$ One should not be led to believe that forging such an intimate bond with God can be effected in an adenominational manner. Zubiri notes that that is possible only within some specific religion. ${ }^{78}$ He himself draws inspiration from Christianity, outlining the image, or concept of God, and then verifies it within the Christian religion as well - this is evidenced by the features of the relation between man and God described above, as well as the fact that he and his wife were churchgoing Catholics (Benedictine oblates). The truthfulness of the outlined foundation (some hypothesis as to what the foundation might be) is therefore corroborated at the level of not only intellect and will, but also of emotions, i.e. at the level of the entire person. ${ }^{79}$ Verification may be of lesser or greater magnitude depending on consequences in a personal life, when it becomes strengthened as a result of entrustment to God. ${ }^{80}$ Entrustment to God is not a one-off act, but a constant attitude (actitud) towards Him. ${ }^{81}$

There are various forms of verification of the outlined image of God; they consist in "physical testing" it in one's own life. One of the forms of testing, or verification is "co-penetrating" (compenetración). This type of experience consists in allowing God - provided that He is a person giving Himself to others - to penetrate me. Such co-penetration can be exemplified by the history of Israel, when the nation entrusts itself to God in its history, experiencing a confirmation that God really acts, because He intervenes in its history, protecting it, i.e. strengthening personal lives of individuals. Thus, Zubiri means a personal experience of God's

77 See X. Zubiri, El hombre y Dios, op. cit., p. 269.

78 See X. Zubiri, El hombre y Dios, op. cit., p. 235; X. Zubiri, El problema filosófico de la historia..., op. cit., p. 83; J. Sáez Cruz, La accesibilidad de Dios..., op. cit., p. 214.

79 See X. Zubiri, El hombre y Dios, op. cit., p. 224.

80 See X. Zubiri, Inteligencia y razón, op. cit., p. 269.

81 See X. Zubiri, El hombre y Dios, op. cit., p. 271. 
action. He straight out says that God is "my" God. ${ }^{82}$ Another type of experience is "conformation" (conformación). By way of conformation I place in my reality an outline of the possibilities resulting from that which I am or could be, if God is the way I outline Him. In the case of the foundation of reality outlined earlier, I can assume that I am a divine donation (donación divina). ${ }^{83}$

As he entrusts himself to God, man should experience that which is not experienced by him who does not entrust himself to God (if the outlined image of God is true). In this entrustment - and Zubiri says this openly - man attains some cognition of God and light that transcend the capabilities of his personal intelligence. ${ }^{84}$ It might not be an overinterpretation with regard to Zubiri's thought to say that God "mystically" provides man with a confirmation that $\mathrm{He}$ is, and what $\mathrm{He}$ is like. ${ }^{85}$ In other words, God is supposed to be the one who in an empirical manner not only strengthens my self - which he does to a greater degree than in the case of other verified outlines of God - but also instructs my self from within. ${ }^{86}$ It is then that the outlined image of God is proved, as a necessary and not additional element in the creation of my self. ${ }^{87}$

The above analyses serve to clarify Zubiri's statement that opting for God-foundation is rational (razional). It is the intellect that discovers religation-founded grounds for this entrustment. But entrustment to God no longer belongs to the rational sphere, but the sphere which is a further consequence of rationality, because it is will that chooses whether to enter into an intimate relationship with God thus outlined, entrusting my entire self to Him. Entrustment is reasonable (razonable). It depends on a personal attitude, which means that apart from the intellect, it involves

82 See X. Zubiri, Inteligencia y razón, op. cit., pp. 249-251; X. Zubiri, El hombre y Dios, op. cit., p. 121.

83 X. Zubiri, Inteligencia y razón, op. cit., pp. 254-257; J. Sáez Cruz, La accesibilidad de Dios..., op. cit., pp. 220-221; F. Llenín Iglesias, La realidad divina..., op. cit., p. 95.

84 See X. Zubiri, El problema filosófico de la historia..., op. cit., pp. 82-83.

85 Of course this is about natural mysticism: R. S. Niziński, Zubiri como místico, "The Xavier Zubiri Review" 14 (2016-2018), pp. 73-85.

86 Cf. A. Pintor-Ramos, Religación y..., op. cit., p. 331.

87 See X. Zubiri, El hombre y Dios, op. cit., p. 202. 
will and feelings. Man wants to consolidate his personal life by adhering to the source of reality. Zubiri even goes as far as to speak about love for God as a form of adhering to Him. Love is one of the conditions for verification of the image of God. ${ }^{88}$ Hence, Zubiri can say that reasonableness is something more than rationality. ${ }^{89} \mathrm{~A}$ rational image of God is an image explicated by the intellect, and a reasonable image is trustworthy, because it has been tried and tested in one's own life. ${ }^{90}$ A reasonable image of God is also one that is not perfectly consistent with reality (otherwise it would be rational), but it is coincident with it, i.e. it is some consequence of rationality. It is coincident with the direction proposed by reality. ${ }^{91}$ This is to mean that the reality perceived proposes to man a certain way of looking for the foundation.

Therefore, to conclude, Zubiri's concept of the way leading to cognition of God does not directly demonstrate the existence or nature of God, but only indicates that that which is given (the manner of creating the Self) contains something that can be termed God (it is the features of the foundation of reality that allow it to create the Self). ${ }^{92}$ That is why the cognition is demonstrative, which means that at the level of intellectual cognition there are certain premises that something like God might exist. ${ }^{93}$

Unlike Thomas Aquinas' philosophy, Zubiri's way of religation is not a path leading through Greek terms, because it is an argument from a man's personal life. ${ }^{94}$ It is a "test" undertaken in one's own personal life. ${ }^{95}$ In a way, it is in his own life that man becomes convinced that his hypothesis as to who God might be proves to be true. The outline of God,

88 See X. Zubiri, El problema filosófico de la historia..., op. cit., p. 257.

89 See X. Zubiri, El hombre y Dios, op. cit., pp. 276-277, 434-435.

90 See X. Zubiri, El problema filosófico de la historia..., op. cit., p. 283.

91 See X. Zubiri, El problema filosófico de la historia..., op. cit., p. 283; M. D. González, Dios, problema de todos, op. cit., pp. 81-84.

92 Cf. A. Pintor-Ramos, Religación y..., op. cit., p. 227.

93 See X. Zubiri, El hombre y Dios, op. cit., pp. 246-247.

94 See X. Zubiri, El hombre y Dios, op. cit., pp. 168-169; M. D. González, Dios, problema de todos, op. cit., pp. 79, 82; A. Pintor-Ramos, Religación y..., op. cit., p. 323; M. Jagłowski, Realizm transcendentalny..., op. cit., pp. 225-227.

95 See X. Zubiri, El hombre y Dios, op. cit., pp. 246-247. 
which has been proven in entrustment, is something more than a mere concept, because it turns out to be the real principle of my personal life. And this allows God thus "proven" to be a God of religion as well.

Following Zubiri's method, the last step is to understand reality from the perspective of the already familiar foundation. This is accomplished through a return to the thing from the perspective of that which that thing "really is," i.e. when we already know what the foundation of reality is. This is about seeing how God as the foundation of reality affects what things are, and how I create my Self on the basis of reality. ${ }^{96}$ This is about explicating the enigmatic nature of the power of reality that creates the Self. Zubiri reaches the conclusion that every thing is a reality in its own right, and at the same time something grounded in God. Every thing is a personal donation of God. God is transcendent in things. He is a personal foundation of all things, which convey His power. Without Him things would not be able to determine the Self, because they would be devoid of realness. God Himself (in Himself) is an absolutely absolute reality. ${ }^{97} \mathrm{He}$ gives Himself to Himself. If $\mathrm{He}$ wants to, $\mathrm{He}$ also gives Himself to the reality that is external to Him. Things and man are God ad extra. ${ }^{98}$

Zubiri distances himself from his method, even though he considers it to be absolutely conclusive. While he manages to explain the problem of creation of the human Self, he concludes that his own outline of God - though borne out in experience - is not a definitive solution to the problem of religation, because there is no definitive solution. Becoming cognizant of the foundation of reality is but a march towards the truth, because we can only be approaching the truth. One can at most speak about some similarity of the outlined foundation in relation to that which is given in the process of creation of the Self. ${ }^{99}$ As he follows his path,

96 See X. Zubiri, Inteligencia y razón, op. cit., pp. 336-337.

97 Cf. J. Sáez Cruz, La accesibilidad de Dios..., op. cit., p. 222; A. Pintor-Ramos, Dios y..., op. cit., p. 113.

98 See X. Zubiri, El hombre y Dios, op. cit., p. 478.

99 See X. Zubiri, El hombre y Dios, op. cit., pp. 280-281; see X. Zubiri, Inteligencia y razón, op. cit., pp. 262-264. 
Zubiri concludes that it is the Christian image of God that best expounds the problem in question, i.e. one of creation of the Self, even though such a solution is a makeshift one. ${ }^{100}$ Framing the matter like this is related to the above-mentioned theory of Zubiri's (rational) truth which is only about the convergence of the outlined image of God, and not its complete conformity with the real foundation. ${ }^{101}$ That is why the truthfulness of the outline in this proof has many gradations. Verified as positive, the images of God may be more or less true, as well as false - depending on the degree of convergence. ${ }^{102}$

\section{Critical remarks and problematic issues ${ }^{103}$}

1. In Zubiri's "proof" the criterion for outline verification is twofold: (a) a bond with (the outlined) God experienced in entrustment to Him (as part of some religion) must empirically prove me as a person in the entirety of the dynamic personal development, and (b) the outlined image of God (to whom I entrusted myself) should enable and explicate religation. While the latter criterion is clear, the former one poses some difficulties. Antonio Pintor-Ramos claims that if a human life, in the light of such an outlined foundation placed within a personal life, is richer and truer than in other cases, then in this case this serves as a proof that the foundation thus outlined is to be understood as God, because for Zubiri God is the one who offers man the fullness of being (ser) and life. ${ }^{104} \mathrm{We}$

100 See X. Zubiri, El hombre y Dios, op. cit., p. 15; cf. A. Pintor-Ramos, Dios y..., op. cit., pp. 115-116.

101 See X. Zubiri, Inteligencia y razón, op. cit., p. 264; X. Zubiri, El problema filosófico de la historia..., op. cit., p. 155.

102 See X. Zubiri, El problema filosófico de la historia..., op. cit., pp. 156-157; X. Zubiri, Inteligencia y razón, op. cit., pp. 258, 270; J. Sáez Cruz, La accesibilidad de Dios..., op. cit., p. 194; A. PintorRamos, Dios $y . .$. , op. cit., pp. 114-116.

103 The question of the method employed by Zubiri is a subject that he thoroughly analyses, and so it would be difficult here to give account thereof or take a stand on it, as this would require at least one additional paper. The present paper presents it only briefly so as to outline the very essence of Zubiri's "proof."

104 See A. Pintor-Ramos, Religación y..., op. cit., p. 331. 
know, however, that Zubiri's method necessitates corroboration of the truthfulness of the image of God outlined in a person's soul within the religious context, and every believer is provided with corroboration of the truthfulness of his religious image of God as part of his religion.

This gives rise to a question as to how on the grounds of inner experience I can evaluate the degree of conformity of the outline (image) of God subject to verification with who I am? The problematic nature of this criterion can be observed in Enzo Solari's discussion of the attempts at evaluating the truthfulness of particular religions. These attempts are guided by criteria similar to the ones applicable to the way leading to philosophical cognition of God. Solari acknowledges Zubiri's adoption of the historical criterion as the most reliable one in verification of religious truth, and it is in this criterion too that he places the criterion of individual corroboration of the truthfulness of the outline. It is human history as formed by individuals and societies that is the one allowing verification of that which is offered by particular religious ways. Solari recognises that for Zubiri, at least in some of his statements, it is the history of religion as the only possible tribunal that creates a possibility for evaluating the realisation of religious outlines, and makes it possible to establish whether the image of God proposed by some religion can be accepted as true. ${ }^{105}$ With this statement of Solari's one may get the impression that Zubiri himself was looking for a criterion for verification of the truthfulness of the outline that would be more objective than an individual feeling of enrichment of one's personal life.

2. Zubiri raises an objection to Thomas' proposal, claiming that in the experience of creation of beings we do not deal with causality, but only with a sequence of events, and so speaking about a cause and effect is but a theory. Does the intellect - in the experience of religation really has direct access - which is what Zubiri posits - to the nature of reality's effect on the person? Is it a fact that when things appear in my consciousness, it takes on a new state (a new form of being)? While he

105 See E. Solari, La raíz de lo sagrado..., op. cit., p. 360. He quotes after: X. Zubiri, El problema filosófico de la historia..., op. cit., pp. 206-207, 362-363. 
rejects the possibility of directly knowing the nature of the relationship between things in sensual experience (which allows him to reject Thomas' proofs), he finds such a possibility in the process of creation of the Self, where the intellect would be the direct witness to this creative process. But are we not already at this moment lapsing into some kind of theory? Why would this type of cognition be more certain than sensual experience and its attendant conviction that a thing creates a thing? Hence, the first objection to Thomas' proposal does not appear to be definitively overcome within the method put forward by Zubiri, because he himself introduces his own theory here.

3. Is it a fact that things are an indispensable element in the creation of the Self? According to philosophers of dialogue it is only a person in a personal relationship with another person that performs a person-formative function towards the latter. The presence of things in consciousness only enables the person to function at a conscious (mental), but not personal level. ${ }^{106}$

4. Why is only being something ultimate - and not, for instance, something that creates from nothing, or a necessary being - supposed to testify to being God? Can a reality possessing the latter two characteristics not be a foundation for entering into a religious relationship with it? The question is whether a religious relationship is possible only with such a God who enables my personal life. The image of God obtained by Zubiri shows a God that is a God of above all my personal life. The question is whether that is enough.

As we return to the question posed in the introduction, we can agree that the image of God presented by Zubiri is consistent with the way philosophy and religion understand God. However, it is doubtful whether the method for cognition of God presented by Zubiri may be used outside his philosophical system based on a disputable concept of religation. 


\section{Abstract \\ Rationality vs Reasonableness of the Philosophical Way to God. The Thought of Xavier Zubiri}

The majority of the philosophical proves of the existence of God or other philosophical attempts of talking about Him try to meet standards of rationality only. In this way they reach mostly a philosophical notion of God which rules out a religious relationship to Him. Zubiri is trying to present a philosophical way which leads to a notion of God, who can be at the same time a God of philosophy and of religion. But this means overcoming rationality with reasonableness. Reasonable means compatible with human life.

\section{Keywords}

person, personality, power of the real, experience

\section{Bibliography}

Augustyn z Hippony, O wolnej woli, trans. A. Trombala, in: Augustyn z Hippony, Dialogi filozoficzne, Kraków 1999, pp. 493-649.

Buber M., Słowa - zasady, trans. K Bukowski, “Znak” 26 (1974) no. 3, pp. 291-310.

Díaz Muńoz G., Búsqueda de Dios en el misterio según X. Zubiri, "Estudios Eclesiásticos” 84 (2009) no. 328, pp. 131-162.

Ferraz Fayos A., Zubiri: el realismo radical, Madrid 1988.

González M. D., Dios, problema de todos, in: Voluntad de vida. Ensayos filosóficos, Seminario Zubiri - Ellacuría, Managua 1993, pp. 77-91.

Gracia D., El tema de Dios en la filosofía de Zubiri, "Estudios Eclesiásticos” 56 (1981) no. 216-217, pp. 61-78.

Hartshorne Ch., Man's Vision of God and the Logic of Theism, Connecticut 1964. Jagłowski M., Realizm transcendentalny Xaviera Zubiriego, Olsztyn 2000.

Janka F. T., Jana Dunsa Szkota dowód na istnienie Boga, in: Primum philosophari. Opuscula Antonio Siemianowski dedicata, Poznań 2016, pp. 115-132.

Jędraszewski M., Bóg filozofów i Bóg Jezusa Chrystusa, Poznań 2011. Kant I., Krytyka praktycznego rozumu, trans. J. Gałecki, Warszawa 1972. 
Llenín Iglesias F., La realidad divina. El problema de Dios en Xavier Zubiri, Oviedo 1990. Niziński R. S., Panenteísmo en la filosofía de Xavier Zubiri, "The Xavier Zubiri Review" 14 (2016-2018), pp. 5-15.

Niziński R. S., Zubiri como místico, "The Xavier Zubiri Review” 14 (2016-2018), pp. 73-85.

Pintor-Ramos A., Dios y el problema de la realidad en Zubiri, "Cuadernos de Pensamiento" 1987 no. 1, pp. 107-121.

Pintor-Ramos A., Religación y "prueba" de Dios en Zubiri, "Razón y Fe" 218 (nov. 1988) no. 1081, pp. 319-336.

Potępa M., Obraz człowieka w hermeneutyce Schleiermachera, 'Analiza i Egzystencja" 19 (2012), pp. 113-132.

Sáez Cruz J., La accesibilidad de Dios: su mundanidad y transcendencia en X. Zubiri, Salamanca 1995.

Solari E., La raíz de lo sagrado. Contribuciones de Zubiri a la filosofía de la religión, Santiago de Chile 2010.

Thomae Aquinatis, Summa theologiae, pars I, Matritii 1978. Zubiri X., El hombre y Dios, Nueva edición, Madrid 2012.

Zubiri X., Naturaleza, Historia, Dios, Madrid 2007. Zubiri X., Inteligencia y razón, Madrid 2008.

Zubiri X., Inteligencia y logos, Marid 2008.

Zubiri X., Inteligencia sentiente, vol. 1: Inteligencia y realidad, Madrid 2011. Zubiri X., El problema filosófico de la historia de las religiones, Madrid 2006. 